\title{
Nutritional Evaluation of Sugarcane Cultivars for Ruminants
}

\author{
André Sanches de Avila \\ Animal Science, State University of Western Parana \\ 1777 Pernambuco Street, Marechal Cândido Rondon, Parana, Brazil. \\ E-mail: sanches989@hotmail.com \\ Maximiliane Alavarse Zambom \\ Animal Science, State University of Western Parana \\ 1777 Pernambuco Street, Marechal Cândido Rondon, Parana, Brazil. \\ E-mail: mazambom@hotmail.com \\ Gabriele Larissa Hoelscher \\ Agronomy, State University of Western Parana \\ 1777 Pernambuco Street, Marechal Cândido Rondon, Parana, Brazil. \\ E-mail: gaby.glh@hotmail.com \\ José Barbosa Duarte Júnior \\ Agronomy, State University of Western Parana \\ 1777 Pernambuco Street, Marechal Cândido Rondon, Parana, Brazil. \\ E-mail: bduarte7@yahoo.com.br
}

Andressa Faccenda

Animal Science, State University of Maringa

5790 Colombo Avenue, Maringa, Parana, Brazil.

E-mail: andressafaccenda@hotmail.com 
Maria Luiza Fischer

Animal Science, State University of Western Parana

1777 Pernambuco Street, Marechal Cândido Rondon, Parana, Brazil.

E-mail: maria.luiza.fischer@ hotmail.com

\title{
Angela Fernanda Storti
}

Animal Science, State University of Western Parana

1777 Pernambuco Street, Marechal Cândido Rondon, Parana, Brazil.

E-mail: angela_storti@hotmail.com

Josias Luis Fornari

Animal Science, State University of Western Parana

1777 Pernambuco Street, Marechal Cândido Rondon, Parana, Brazil.

E-mail: josiasfornari@hotmail.com

Maichel Jhonattas Lange

Animal Science, State University of Western Parana

1777 Pernambuco Street, Marechal Cândido Rondon, Parana, Brazil.

E-mail: maichel_j1@hotmail.com

Received: Apr. 22, 2020

doi:10.5296/jas.v8i2.16886
Accepted: May 18, 2020 Published: May 26, 2020

URL: https://doi.org/10.5296/jas.v8i2.16886

\begin{abstract}
The objective of this study was to evaluate the nutritional quality of twenty-nine cultivars of sugarcane. The design was completely randomized, with twenty-nine treatments (cultivars) and three replicates. The evaluations were performed at 540 days after planting during the phenological stage of maturation of sugar cane. Stalk length, number of nodes per plant, internodes length and stalk diameter were evaluated. The stalk samples were crushed, pre-dried and ground for achievement of chemical analysis, carbohydrate fractionation and in vitro digestibility of dry matter (DM), organic matter (OM) and neutral detergent fiber (NDF).
\end{abstract}


Data were analyzed by analysis of variance and posteriorly submitted to Scott-Knott test at $5 \%$ probability. Regarding biometric measurements the cultivars differed $(\mathrm{P}<0.05)$ for the stalk length, but there was no difference $(\mathrm{P}>0.05)$ in the number of nodes as well as in the average internode length and stalk diameter. The content of DM, OM, protein, ether extract, NDF and acid detergent fiber showed differences between the cultivars evaluated $(\mathrm{P}<0.05)$. Carbohydrate fractionation also differed between cultivars $(\mathrm{P}<0.05)$, being that cultivars RB86 7515, RB92 806 and RB03 6091 presented high fraction of rapidly degradable carbohydrates. The highest values of in vitro digestibility of DM and OM occurred for cultivars RB86 7515, RB92 579 and RB03 6091 (P<0.05). Considering the variables analyzed, the cultivars RB03 6091, RB92 579 and RB86 7515 showed greater concentration of rapidly degradable carbohydrates and greater in vitro digestibility of DM and OM demonstrating potential for use in ruminant feeding.

Keywords: bromatological, carbohydrate fractionation, forage, in vitro digestibility

\section{Introduction}

Sugarcane is an alternative widely used in the feeding of ruminants and stands out for its high potential in the production of dry matter and energy per hectare, easy cultivation, resistance and conservation capacity in the field (Mello et al. 2006; Oliveira et al. 2012; Costa et al., 2017).

This forage also presents high levels of soluble carbohydrates (Silva et al., 2008) with sugar content of up to $50 \%$ of dry matter (Oliveira et al., 2007). However, there are some disadvantages to its use, such as low protein and mineral content and high content of indigestible fiber and lignin (Ezequiel et al., 2005). The fibrous fraction can be $60 \%$ indigestible (Fernandes et al., 2003), which causes rumen repletion and reduction of dry matter intake (Siqueira et al., 2012).

Due to these factors, it is indicated that the inclusion of sugar cane in the diet of dairy cows does not exceed $40 \%$ of the total dry matter. Sugar cane can be supplied fresh, ensiled or hydrolyzed (Siqueira et al., 2012). In the fresh form, due to the low concentration of protein, usually the sugar cane is mixed with a solution of urea and ammonium sulfate that serve as a source of nitrogen and sulfur, respectively, for the synthesis of microbial protein in rumen (Tiago and Vieira, 2002). When ensiled, the sugarcane fermentation process provides intense activity of epiphytic yeasts, which reduce the nutritional value and increase losses during storage. Thus, sugarcane ensilage requires the use of microbial additives to minimize these losses. In the case of hydrolysis, alkaline agents are added to sugar cane to solubilize the fiber and control unwanted microorganisms. However, the advantages obtained with the increase in fiber solubility are negatively offset by losses of soluble carbohydrates (Siqueira et al., 2012).

An important factor to consider is the use of cultivars having characteristics to allow a good performance to animals. The numerous existing cultivars have quite diverse characteristics, and specifically when intended for animal feed, the main characteristics evaluated are the production, the harvest facility and nutritional quality, observing not only its sugar content, 
but also the fiber quality (Freitas et al., 2006).

Selecting sugarcane genotypes with lower NDF content and higher NDF digestibility may be a strategy for improving the efficiency of sugarcane-based production systems (Daniel et al., 2016). Thus, the objective of this study was to evaluate the nutritional value regarding bromatological composition, carbohydrate fractionation and in vitro digestibility of dry matter, organic matter and neutral detergent fiber of different sugarcane cultivars and select the best profile for ruminant nutrition.

\section{Material and Methods}

The experiment was carried out in the city of Marechal Cândido Rondon, PR, Brazil. Located at $24^{\circ} 33^{\prime} 22$ "S 54 03'24" W, $400 \mathrm{~m}$. alt. Soil from experimental area is classified as Eutrophic Red Latosol (LVe) (Santos et al., 2013).

Prior to the cultivation of sugarcane, the area was in a state of fallow, without any cultivation. Soil analysis was performed to determine its chemical characteristics before the culture implantation (Table 1) and subsequently its results used for soil correction, based on culture requirements.

The climate of the region according to the Köppen climate classification is Cfa type, subtropical humid mesothermal of dry winter, with well-distributed rainfall throughout the year and hot summers. The average temperatures of the coldest quarter ranged between $17^{\circ} \mathrm{C}$ and $18{ }^{\circ} \mathrm{C}$ and the warmest quarter between $28^{\circ} \mathrm{C}$ and $29^{\circ} \mathrm{C}$. The crop was not irrigated, and average annual rainfall for the region ranges from 1,600 to $1,800 \mathrm{~mm}$, with the wettest quarter showing totals ranging from 400 to $500 \mathrm{~mm}$ (Caviglione, 2000).

Table 1. Chemical characteristics of the soil, in the 0 to $40 \mathrm{~cm}$ deep layer, in the area before the implantation of sugarcane cultivars.

\begin{tabular}{c|c|c|c|c|c|c|c|c|c|c|c}
\hline Depht & $\mathrm{P}$ & $\mathrm{pH}$ & $\mathrm{H}+\mathrm{Al}$ & $\mathrm{Al}^{3+}$ & $\mathrm{K}^{+}$ & $\mathrm{Ca}^{2+}$ & $\mathrm{Mg}^{2+}$ & $\mathrm{SB}$ & $\mathrm{CEC}$ & $\mathrm{V}$ \\
\hline $\mathrm{cm}$ & $\mathrm{mg} \mathrm{dm}^{-3}$ & $\mathrm{CaCl}_{2}$ & \multicolumn{6}{|c}{$----------\mathrm{cmol}_{\mathrm{c}} \mathrm{dm}^{-3}$} & ------------- & & $\%$ \\
\hline $0-10$ & 19.25 & 4.75 & 6.16 & 0.19 & 0.36 & 4.59 & 1.75 & 6.70 & 12.87 & 52.12 \\
\hline $10-20$ & 35.36 & 4.65 & 6.35 & 0.36 & 0.30 & 4.41 & 1.51 & 6.22 & 12.56 & 49.47 \\
\hline $20-40$ & 12.80 & 4.92 & 5.00 & 0.00 & 0.27 & 4.31 & 1.53 & 6.11 & 11.10 & 54.95 \\
\hline
\end{tabular}

SB: sum of bases; CEC: Cation Exchange Capacity; V: soil base saturation;

The sugarcane cultivars were planted in October, 2013. The field experiment was performed with the intention of multiplying the genotypes, therefore, it was composed of a clonal garden where each cultivar was randomly implanted in one plot of $2.5 \times 4 \mathrm{~m}$. The design was completely randomized and the treatments were the twenty-nine sugarcane cultivars: RB92 5345; RB86 5230; RB95 6911; RB83 5486; RB83 5089; RB 845210; RB98 6419; RB03 6066; RB03 6088; RB86 7515; RB96 6928; RB85 5113; RB92 579; RB03 6085; RB85 5035; RB85 5453; RB03 6059; RB03 6091; RB01 6916; RB94 6903; RB85 5546; RB01 6913; RB85 5036; RB03 6152; RB83 5054; RB85 5156; RB85 5536; RB92 8064; RB72 454. Of these cultivars, twenty-three of them are commercialized, while others six was not available 
for commercialization.

The cut for laboratory evaluations was made at 540 days of culture implantation, on April 17, 2015, consisting in a plant-cane cicle which coincided with the phenological stage of maturation. Three plants were randomly selected from each cultivar which were manually harvested with a cut close to the soil. The upper part of sugarcane was removed, making the cut in the last visible node, dry leaves were also removed, evaluating stem composition.

The biometric measurements evaluated were: stalk length (SL), stalk diameter (SD,) number of nodes per plant (NN) and average internodes length (IL) using a metric tape and caliper.

Subsequently, plants stalks were crushed and transported to the laboratory, pre-dried in a $55^{\circ}$ $\mathrm{C}$ forced-air oven and ground in a Willey type grinder (sieve size $1 \mathrm{~mm}$ ) for further analysis. Dry matter (DM), ash, crude protein $(\mathrm{CP})$ and ether extract (EE) contents were evaluated according to AOAC (1990). Neutral detergent fiber (NDF), acid detergent fiber (ADF) according to Van Soest et al. (1991). The organic matter (OM) content was calculated according to the formula: $\mathrm{OM}=100-\%$ ash.

Carbohydrate fractionation and total carbohydrates were determined according to Sniffen et al. (1992): A: soluble sugars with rapid ruminal degradation; B1: rapidly degradable carbohydrates (starch and pectin); B2: potentially degradable carbohydrates with slow degradation rate; $\mathrm{C}$ : indigestible carbohydrates.

In vitro digestibilities of dry matter (IVDMD) and organic matter (IVOMD) were estimated by the technique of Tilley and Terry (1963) and adapted to artificial rumen, developed by ANKOM ${ }^{\circledR}$, as described by Holden (1999). To determine the in vitro digestibility of neutral detergent fiber (IVNDFD), the methodology described by Goering and Van Soest (1975) was adopted, with samples incubated for 48 hours at a temperature of $39{ }^{\circ} \mathrm{C}$, since pepsin and hydrochloric acid digestion was not performed, then was analyzed the NDF content of the residue (Ankom220 Fiber Analyzer).

The study was carried out in a completely randomized design and the data were submitted to analysis of variance (ANOVA) according to the statistical model:

$$
Y i j=\mu+T i+E i j
$$

Where: Yij = observed value of the studied characteristic, in treatment $\mathrm{i}$ and in repetition $\mathrm{j} ; \mu$ $=$ overall mean; $\mathrm{Ti}=$ effect of the treatment $\mathrm{i}$; Eij = error associated with Yij observation. When significant, the means were grouped by the Scott Knott test, considering the level of $5 \%$ probability.

\section{Results and Discussion}

Regarding biometric measurements (Table 2), the 15 cultivars with the highest values (P $<0.05)$ for the stalk length had average values of $2.78 \mathrm{~m}$ while the cultivars with the smallest stalk length had average values of $2.24 \mathrm{~m}(\mathrm{P}<0.05)$. The stalk size had differences in cultivars ranging from $1.74 \mathrm{~m}$ to $3.04 \mathrm{~m}$. In the cultivars RB86 7515 and RB92 579 there were values of 2.53 and $2.11 \mathrm{~m}$ respectively, being lower than those obtained by Magalhães et al. (2018) 
with an average of $3.49 \mathrm{~m}$ TC 12 months after planting.

There was no difference $(\mathrm{P}>0.05)$ between the cultivars in the number of nodes as well as in the average internode length and stalk diameter. The variable number of nodes may have a negative correlation with the ease of cutting and digestibility, because this portion has a higher proportion of indigestible fiber (Klein, 2010). Internode length according to Bonomo et al. (2009) is an important characteristic to be considered because it concentrates the highest quantity and quality of soluble carbohydrates. The authors also emphasize that the internode length is a characteristic related to the genotype and may to be influenced by environmental conditions, reducing its size in cases of water deficit.

Table 2. Biometric measurements sugarcane cultivars

\begin{tabular}{c|c|c|c|c}
\hline Cultivar & SL $(\mathrm{m})$ & NN & IL $(\mathrm{cm})$ & SD $(\mathrm{mm})$ \\
\hline RB92 5345 & $2.44 \mathrm{~b}$ & 21.67 & 14.33 & 31.33 \\
\hline RB86 5230 & $2.54 \mathrm{a}$ & 32.00 & 6.50 & 31.23 \\
\hline RB95 6911 & $2.80 \mathrm{a}$ & 20.67 & 17.37 & 26.63 \\
\hline RB83 5486 & $2.70 \mathrm{a}$ & 17.33 & 19.20 & 30.13 \\
\hline RB83 5089 & $2.06 \mathrm{~b}$ & 17.33 & 13.67 & 32.47 \\
\hline RB84 5210 & $2.34 \mathrm{~b}$ & 22.00 & 10.33 & 28.43 \\
\hline RB98 6419 & $2.39 \mathrm{~b}$ & 19.67 & 17.67 & 33.50 \\
\hline RB03 6066 & $3.03 \mathrm{a}$ & 32.33 & 9.33 & 32.50 \\
\hline RB03 6088 & $2.85 \mathrm{a}$ & 22.67 & 14.00 & 30.90 \\
\hline RB86 7515 & $2.53 \mathrm{~b}$ & 22.00 & 14.33 & 29.77 \\
\hline RB96 6928 & $3.38 \mathrm{a}$ & 34.00 & 13.33 & 24.83 \\
\hline RB85 5113 & $2.60 \mathrm{~b}$ & 22.33 & 13.90 & 26.17 \\
\hline RB92 579 & $2.11 \mathrm{~b}$ & 26.67 & 10.67 & 30.13 \\
\hline RB03 6085 & $2.27 \mathrm{~b}$ & 20.00 & 13.17 & 40.47 \\
\hline RB85 5035 & $2.12 \mathrm{~b}$ & 19.33 & 13.00 & 29.40 \\
\hline RB85 5453 & $2.67 \mathrm{a}$ & 23.33 & 14.67 & 31.90 \\
\hline RB03 6059 & $2.74 \mathrm{a}$ & 27.67 & 10.33 & 29.07 \\
\hline RB03 6091 & $2.18 \mathrm{~b}$ & 18.33 & 12.50 & 33.53 \\
\hline RB016916 & $2.17 \mathrm{~b}$ & 20.00 & 11.33 & 33.60 \\
\hline RB946903 & $2.97 \mathrm{a}$ & 23.00 & 15.57 & 24.77 \\
\hline RB85 5546 & $2.49 \mathrm{a}$ & 23.00 & 16.17 & 31.87 \\
\hline RB016913 & $2.64 \mathrm{a}$ & 22.33 & 12.50 & 26.93 \\
\hline RB85 5036 & $2.27 \mathrm{~b}$ & 24.33 & 13.33 & 27.20 \\
\hline RB03 6152 & $1.74 \mathrm{~b}$ & 10.67 & 15.33 & 26.47 \\
\hline RB83 5054 & $2.61 \mathrm{a}$ & 18.67 & 18.67 & 31.67 \\
\hline RB85 5156 & $3.04 \mathrm{a}$ & 29.00 & 13.47 & 28.83 \\
\hline RB85 5536 & $2.18 \mathrm{~b}$ & 23.33 & 10.77 & 30.57 \\
\hline RB92 8064 & $2.61 \mathrm{a}$ & 22.00 & 16.83 & 31.77 \\
\hline RB72 454 & $2.75 \mathrm{a}$ & 16.33 & 22.50 & 30.97 \\
\hline SEM & 0.17 & 3.72 & 2.27 & 2.22 \\
\hline & & & & \\
\hline
\end{tabular}

Means followed by different letters in the column differ statistically by the Scott-Knott test at 5\% probability. SL: Stalk Length; NN: number of nodes; IL: average internode length; SD: Stalk diameter; SEM: Standard error of mean. 
Dry matter values (Table 3) were between $231.5 \mathrm{~g} \mathrm{~kg}^{-1}$ (RB86 7515) and $301.5 \mathrm{~g} \mathrm{~kg}^{-1}$ with the highest values $(\mathrm{P}<0.05)$ for the cultivar RB 85 5536. Daniel et al. (2016) evaluated 32 varieties in second cut (ratoon cane) with 12 months after the budding and obtained average values of $325 \mathrm{~g} \mathrm{~kg}^{-1}$ with minimum and maximum values of $276 \mathrm{~g} \mathrm{~kg}^{-1}$ and $360 \mathrm{~g} \mathrm{~kg}^{-1}$, respectively. Miranda et al. (2015) evaluated three sugarcane cultivars during three harvests and obtained average values of $235.46 \mathrm{~g} \mathrm{~kg}^{-1}$, the authors related the low DM content to the high rainfall in the month of harvest (Muraro et al., 2009).

In relation to OM, the highest concentrations were observed for cultivars RB01 6913 and RB85 515, while RB83 5089 presented the lowest concentration ( $\mathrm{P}<0.05)$. According to Siqueira et al. (2012) sugarcane is a feed with low levels of minerals. Bonomo et al. (2009) evaluated 23 cultivars of sugarcane obtained an average of $24.4 \mathrm{~g} \mathrm{~kg}^{-1} \mathrm{DM}$, corroborating the values obtained in the present study.

In terms of protein content, the cultivars RB96 6928, RB83 5089, RB83 5054, RB85 5453 and RB03 6059 stood out in relation to the others with average protein values of 21.7, 19.7, 19.1, 18.8 and $17.8 \mathrm{~g} \mathrm{~kg}^{-1} \mathrm{DM}$ respectively $(\mathrm{P}<0.05)$. Costa et al. (2017) evaluated three sugarcane cultivars including RB86 7515 and RB92 579 and obtained average levels of $17.95 \mathrm{~g} \mathrm{~kg}^{-1} \mathrm{DM}$ for these genotypes, above the values obtained in this study. Magalhães et al. (2018) evaluated different cultivars of sugarcane and obtained average CP values of $21.94 \mathrm{~g} \mathrm{~kg}^{-1}$.

Variations in CP content of cultivars may be due to their intrinsic genetic characteristics, cutting age (Mello et al., 2006) and other factors. Given the low protein values of sugarcane as a forage, supplementation with high protein feed or non-protein nitrogen sources is ideal. According to Segato et al. (2006) sugarcane nutritional restrictions can be minimized by increasing a non-protein nitrogen source in the feed, such as urea, which after ingestion is converted into ammonia and used by ruminal microorganisms for microbial protein synthesis.

Ether extract content varied from 1.2 to $11.2 \mathrm{~g} \mathrm{~kg}^{-1} \mathrm{DM}$. The cultivar RB03 6091 stood out for the highest concentration of this nutrient $(\mathrm{P}<0.05)$, while the cultivars RB86 5230, RB03 6066, RB86 7515, RB96 6928, RB85 5546 and RB85 5036 presented the lowest concentrations. Oliveira et al. (2008) evaluated the cultivars RB83 5453 and IAC86 2480 and obtained respectively EE values of 5.3 and $5.0 \mathrm{~g} \mathrm{~kg}^{-1} \mathrm{DM}$. Bonomo et al. (2009) with 23 sugarcane cultivars obtained an average value of $10.1 \mathrm{~g} \mathrm{~kg}^{-1} \mathrm{DM}$. Andrade et al. (2004) evaluated 60 sugarcane genotypes, and obtained an average EE value of $9.8 \mathrm{~g} \mathrm{~kg}^{-1} \mathrm{DM}$.

Neutral detergent fiber concentration was higher for the RB95 6911 cultivar with $510.7 \mathrm{~g} \mathrm{~kg}^{-1}$ $\mathrm{DM}(\mathrm{P}<0.05)$. The lowest concentration was $314.2 \mathrm{~g} \mathrm{~kg}^{-1} \mathrm{DM}$ observed for cultivar RB03 $6091(\mathrm{P}<0.05)$. The average NDF levels obtained in the present study $\left(398.2 \mathrm{~g} \mathrm{~kg}^{-1} \mathrm{DM}\right) \mathrm{can}$ be considered lesser when related to the results obtained in the studies of Daniel et al. (2016) and Magalhães et al. (2018) with $482 \mathrm{~g} \mathrm{~kg}^{-1} \mathrm{DM}$ and $446 \mathrm{~g} \mathrm{~kg}^{-1} \mathrm{DM}$ respectively. According to Van Soest (1994) in general, NDF values in sugarcane are not high, however, the fiber quality is low, and the increase in NDF content may reduce digestibility.

According to Magalhães et al. (2018) NDF contents lower than $500 \mathrm{~g} \mathrm{~kg}^{-1}$ may increase sugarcane intake by the ruminant, because lesser NDF content in plant, may correspond to a 
higher concentration from cellular content, which is rapidly digestible. In addition, a lesser NDF content may indicate a faster ruminal fermentation rate of cellulose and hemicellulose, due to their lower lignification, and may reduce ruminal repletion, increasing intake and consequently animal production.

Table 3. Bromatological composition (g kg-1 DM) of sugarcane cultivars

\begin{tabular}{|c|c|c|c|c|c|c|}
\hline Cultivar & $\mathrm{DM}$ & $\mathrm{OM}$ & $\mathrm{CP}$ & $\mathrm{EE}$ & $\mathrm{NDF}$ & $\mathrm{ADF}$ \\
\hline RB92 5345 & $251.4 \mathrm{~g}$ & $987.5 \mathrm{~b}$ & $16.2 \mathrm{~b}$ & $4.9 \mathrm{~d}$ & $373.9 \mathrm{~d}$ & $256.7 \mathrm{c}$ \\
\hline RB86 5230 & $251.9 \mathrm{~g}$ & $984.1 \mathrm{c}$ & $10.8 \mathrm{c}$ & $1.2 \mathrm{e}$ & $365.1 \mathrm{e}$ & $266.6 \mathrm{c}$ \\
\hline RB95 6911 & $250.4 \mathrm{~g}$ & $984.9 \mathrm{c}$ & $12.8 \mathrm{c}$ & $3.6 \mathrm{~d}$ & $510.7 \mathrm{a}$ & $328.0 \mathrm{a}$ \\
\hline RB83 5486 & $253.9 \mathrm{~g}$ & $978.4 \mathrm{e}$ & $6.3 \mathrm{~d}$ & $3.5 \mathrm{~d}$ & $484.0 \mathrm{~b}$ & $319.0 \mathrm{a}$ \\
\hline RB83 5089 & $238.2 \mathrm{i}$ & $966.2 \mathrm{~h}$ & $19.7 \mathrm{a}$ & $7.3 \mathrm{c}$ & $429.9 \mathrm{c}$ & $264.8 \mathrm{c}$ \\
\hline RB84 5210 & $268.1 \mathrm{e}$ & $977.2 \mathrm{e}$ & $10.9 \mathrm{c}$ & $4.3 \mathrm{~d}$ & $431.0 \mathrm{c}$ & $283.2 \mathrm{~b}$ \\
\hline RB98 6419 & $241.1 \mathrm{~h}$ & $973.3 \mathrm{f}$ & $15.3 \mathrm{~b}$ & $4.0 \mathrm{~d}$ & $394.5 \mathrm{~d}$ & $247.9 \mathrm{c}$ \\
\hline RB03 6066 & $261.1 \mathrm{f}$ & $990.0 \mathrm{a}$ & $5.3 \mathrm{~d}$ & $1.9 \mathrm{e}$ & $476.8 \mathrm{~b}$ & $317.0 \mathrm{a}$ \\
\hline RB03 6088 & $245.6 \mathrm{~h}$ & $984.0 \mathrm{c}$ & $10.6 \mathrm{c}$ & $5.7 \mathrm{c}$ & $363.4 \mathrm{e}$ & $245.1 \mathrm{c}$ \\
\hline RB86 7515 & $231.5 \mathrm{j}$ & $987.7 \mathrm{~b}$ & $12.9 \mathrm{c}$ & $1.8 \mathrm{e}$ & $341.1 \mathrm{f}$ & $220.9 \mathrm{c}$ \\
\hline RB96 6928 & $257.1 \mathrm{f}$ & $970.1 \mathrm{~g}$ & $21.7 \mathrm{a}$ & $2.2 \mathrm{e}$ & $394.2 \mathrm{~d}$ & $240.1 \mathrm{c}$ \\
\hline RB85 5113 & $258.6 \mathrm{f}$ & $980.5 \mathrm{~d}$ & $15.6 \mathrm{~b}$ & $8.9 \mathrm{~b}$ & $421.5 \mathrm{c}$ & $304.0 \mathrm{a}$ \\
\hline RB92 579 & $251.5 \mathrm{~g}$ & $981.6 \mathrm{~d}$ & $14.5 \mathrm{~b}$ & $8.8 \mathrm{~b}$ & $364.7 \mathrm{e}$ & $257.0 \mathrm{c}$ \\
\hline RB03 6085 & $256.7 \mathrm{f}$ & $971.1 \mathrm{~g}$ & $11.8 \mathrm{c}$ & $5.8 \mathrm{c}$ & $416.3 \mathrm{c}$ & $276.5 \mathrm{~b}$ \\
\hline RB85 5035 & $245.4 \mathrm{~h}$ & $976.4 \mathrm{e}$ & $15.1 \mathrm{~b}$ & $8.7 \mathrm{~b}$ & $420.2 \mathrm{c}$ & $278.7 \mathrm{~b}$ \\
\hline RB85 5453 & $261.1 \mathrm{f}$ & $983.0 \mathrm{c}$ & $18.8 \mathrm{a}$ & $8.3 \mathrm{~b}$ & $388.4 \mathrm{~d}$ & $284.0 \mathrm{~b}$ \\
\hline RB03 6059 & $282.6 \mathrm{c}$ & $981.5 \mathrm{~d}$ & $17.8 \mathrm{a}$ & $8.1 \mathrm{~b}$ & $377.5 \mathrm{~d}$ & $279.5 \mathrm{~b}$ \\
\hline RB03 6091 & $267.7 \mathrm{e}$ & $980.4 \mathrm{~d}$ & $10.0 \mathrm{c}$ & $11.2 \mathrm{a}$ & $314.2 \mathrm{~g}$ & $205.3 \mathrm{c}$ \\
\hline RB01 6916 & $264.3 \mathrm{e}$ & $982.7 \mathrm{c}$ & $14.2 \mathrm{~b}$ & $9.1 \mathrm{~b}$ & $361.3 \mathrm{e}$ & $264.0 \mathrm{c}$ \\
\hline RB94 6903 & $270.5 \mathrm{e}$ & $987.5 \mathrm{~b}$ & $16.6 \mathrm{~b}$ & $5.9 \mathrm{c}$ & $399.6 \mathrm{~d}$ & $276.4 \mathrm{~b}$ \\
\hline RB85 5546 & $246.8 \mathrm{~h}$ & $976.5 \mathrm{e}$ & $14.7 \mathrm{~b}$ & $1.6 \mathrm{e}$ & $424.6 \mathrm{c}$ & $284.0 \mathrm{~b}$ \\
\hline RB01 6913 & $289.1 \mathrm{~b}$ & $989.6 \mathrm{a}$ & $13.9 \mathrm{~b}$ & $3.1 \mathrm{~d}$ & $373.5 \mathrm{~d}$ & $264.8 \mathrm{c}$ \\
\hline RB85 5036 & $250.6 \mathrm{~g}$ & $987.9 \mathrm{~b}$ & $10.8 \mathrm{c}$ & $2.0 \mathrm{e}$ & $369.5 \mathrm{e}$ & $241.3 \mathrm{c}$ \\
\hline RB03 6152 & $283.4 \mathrm{c}$ & $980.1 \mathrm{~d}$ & $6.9 \mathrm{~d}$ & $6.4 \mathrm{c}$ & $363.9 \mathrm{e}$ & $253.6 \mathrm{c}$ \\
\hline RB83 5054 & $275.4 \mathrm{~d}$ & $985.1 \mathrm{c}$ & $19.1 \mathrm{a}$ & $4.2 \mathrm{~d}$ & $374.2 \mathrm{~d}$ & $260.1 \mathrm{c}$ \\
\hline RB85 5156 & $252.1 \mathrm{~g}$ & $989.7 \mathrm{a}$ & $14.1 \mathrm{~b}$ & $5.9 \mathrm{c}$ & $393.5 \mathrm{~d}$ & $255.9 \mathrm{c}$ \\
\hline RB85 5536 & $301.5 \mathrm{a}$ & $976.6 \mathrm{e}$ & $15.9 \mathrm{~b}$ & $8.4 \mathrm{~b}$ & $405.5 \mathrm{~d}$ & $259.8 \mathrm{c}$ \\
\hline RB92 8064 & $268.0 \mathrm{e}$ & $980.8 \mathrm{~d}$ & $11.8 \mathrm{c}$ & $3.3 \mathrm{~d}$ & $346.9 \mathrm{f}$ & $243.1 \mathrm{c}$ \\
\hline RB72 454 & $267.7 \mathrm{e}$ & $986.2 \mathrm{~b}$ & $12.9 \mathrm{c}$ & $3.9 \mathrm{~d}$ & $469.2 \mathrm{~b}$ & $330.3 \mathrm{a}$ \\
\hline SEM & 1.8 & 0.8 & 1.0 & 0.7 & 9.8 & 12.8 \\
\hline
\end{tabular}

Means followed by different letters in the column differ statistically by the Scott Knott Test at 5\% probability. DM: dry matter; OM: organic matter; CP: crude protein; EE: ether extract; NDF: neutral detergent fiber; ADF: acid detergent fiber; SEM: Standard error of mean.

Acid detergent fiber ranged from $205.3 \mathrm{~g} \mathrm{~kg}^{-1}$ (RB03 6091) to $330.3 \mathrm{~g} \mathrm{~kg}^{-1}$ (RB72 454). The cultivars RB95 6911, RB83 5486, RB03 6066, RB85 5113 and RB72 454 showed the highest values $(\mathrm{P}<0.05)$. According to Van Soest (1994) higher ADF content is undesirable because 
this fibrous fraction is negatively correlated with the digestibility of the feed. The mean ADF value observed in this study $\left(269.2 \mathrm{~g} \mathrm{~kg}^{-1} \mathrm{DM}\right)$ were similar to those obtained by Bezerra et al. (2017) who evaluated five RB cultivars with average of $263.4 \mathrm{~g} \mathrm{~kg}^{-1} \mathrm{DM}$.

Regarding carbohydrate fractionation (Table 4), the cultivar RB03 6066 presented the greatest TC value with $982.9 \mathrm{~g} \mathrm{~kg}^{-1} \mathrm{DM}$, while the cultivar RB83 5089 showed the lowest value (939 $\mathrm{g} \mathrm{kg}^{-1} \mathrm{DM}$; P <0.05). The cultivars RB86 7515, RB92 806 and, RB03 6091 presented high fraction of soluble components $(\mathrm{A}+\mathrm{B} 1)$, with average value of $656.1 \mathrm{~g} \mathrm{~kg}^{-1}$ TC, while the lowest values were for the cultivars RB72 454, RB03 6066 and RB83 5486 (P $<0.05)$. The $\mathrm{A}+\mathrm{B} 1$ fraction represents the carbohydrates with greater ruminal degradation, such as soluble sugars and starch (Sniffen et al., 1992) and may positively influence animal performance. The cultivar RB86 7515 is noteworthy because in addition to presenting a higher concentration of the A + B1 fraction, it also had a low NDF content, demonstrating an interesting nutritional value for the feeding of ruminants. Bezerra et al. (2017) evaluated the fractionation of carbohydrates from five cultivars and the highest values for fraction A + B1 were obtained for cultivar RB86 7515, corroborating what was obtained in the present study.

In B2 fraction, cultivars RB95 6911 and RB 835486 showed higher values, while cultivars RB83 5089, RB84 5210, RB03 6066, RB03 6085, RB85 5035, RB85 5546, RB85 5156, RB85 5536 and RB72 454 presented intermediate values $(\mathrm{P}<0.05)$. B2 fraction represents the potentially degradable fiber and according to Sunahara et al. (2018) the highest concentration of this fraction is related to a high NDF content of the food. In the present study, the general average of fraction B2 was $295.1 \mathrm{~g} \mathrm{~kg}-1 \mathrm{CT}$, similar to the obtained by Cruz et al. (2010) that ranged from 273 to $290 \mathrm{~g} \mathrm{~kg}-1$ of TC.

For indigestible carbohydrates ( $\mathrm{C}$ fraction), the cultivars with the greatest value $(\mathrm{P}<0.05)$ were RB92 5345, RB95 6911, RB83 5089, RB03 6066, RB85 5113, RB85 5453, RB03 6059, RB94 6903 and RB72 454 with an average value equivalent to $114.0 \mathrm{~g} \mathrm{~kg}^{-1}$ of TC. The lesser values for $\mathrm{C}$ fraction occurred in eleven cultivars (RB86 5230, RB03 6088, RB86 7515, RB92 579, RB03 6085, RB03 6091, RB85 5036, RB03 6152, RB85 5156, RB85 5536 and RB92 8064) with average values of $70.8 \mathrm{~g} \mathrm{~kg}^{-1}$ of TC. Fraction $\mathrm{C}$ is closely related to the lignin content present in the plant and negatively impacts the digestibility of fibrous carbohydrates (Mello et al., 2006). Thus, in order to use sugarcane to feed ruminants, it is desirable cultivars with a lower content of this fraction.

The highest values of IVDMD and IVOMD (Table 5) occurred for cultivars RB86 7515, RB92 579 and RB03 $6091(\mathrm{P}<0.05)$. This result can be explained by the lower concentration of indigestible carbohydrates ( $C$ fraction) of these three cultivars and by the higher concentration of rapidly degradable carbohydrates $(\mathrm{A}+\mathrm{B} 1$ fraction) in the case of RB86 7515 and RB03 6091. The lowest IVDMD values occurred for RB72 454 and RB95 6911 due to the high concentration of fraction $\mathrm{C}$ of these cultivars and the low content of fraction $\mathrm{A}+$ $\mathrm{B} 1$, in the case of RB72 454. In the general average, the cultivars evaluated presented IVDMD above $650 \mathrm{~g} \mathrm{~kg}^{-1} \mathrm{DM}$, higher than those obtained by Bezerra et al. (2017), Oliveira et al. (2007), Silva et al. (2008) and Schmidt et al. (2007). 
Table 4. Carbohydrate fractionation of sugarcane cultivars

\begin{tabular}{|c|c|c|c|c|}
\hline Cultivar & $\begin{array}{c}\mathrm{TC}\left(\mathrm{g} \mathrm{kg}^{-1} \text { dry }\right. \\
\text { matter })\end{array}$ & $\begin{array}{c}\text { A+B1 Fraction } \\
\left(\mathrm{g} \mathrm{kg}^{-1} \mathrm{TC}\right)\end{array}$ & $\begin{array}{l}\text { B2 Fraction } \\
\left(\mathrm{g} \mathrm{kg}^{-1} \mathrm{TC}\right)\end{array}$ & $\begin{array}{l}\text { C Fraction } \\
\left(\mathrm{g} \mathrm{kg}^{-1} \mathrm{TC}\right)\end{array}$ \\
\hline RB92 5345 & $961.3 \mathrm{~d}$ & $613.9 \mathrm{c}$ & $278.3 \mathrm{c}$ & $107.7 \mathrm{a}$ \\
\hline RB86 5230 & $972.1 \mathrm{~b}$ & $624.8 \mathrm{~b}$ & $299.6 \mathrm{c}$ & $75.6 \mathrm{c}$ \\
\hline RB95 6911 & $968.2 \mathrm{c}$ & $474.8 \mathrm{f}$ & $408.0 \mathrm{a}$ & $117.2 \mathrm{a}$ \\
\hline RB83 5486 & $968.5 \mathrm{c}$ & $502.0 \mathrm{e}$ & $397.5 \mathrm{a}$ & $100.5 \mathrm{~b}$ \\
\hline RB83 5089 & $939.0 \mathrm{~g}$ & $544.2 \mathrm{~d}$ & $349.8 \mathrm{~b}$ & $105.9 \mathrm{a}$ \\
\hline RB84 5210 & $962.0 \mathrm{~d}$ & $570.1 \mathrm{~d}$ & $336.3 \mathrm{~b}$ & $93.5 \mathrm{~b}$ \\
\hline RB98 6419 & $953.3 \mathrm{e}$ & $587.3 \mathrm{c}$ & $326.4 \mathrm{c}$ & $96.3 \mathrm{~b}$ \\
\hline RB03 6066 & $982.9 \mathrm{a}$ & 515.9 e & $359.9 \mathrm{~b}$ & $124.1 \mathrm{a}$ \\
\hline RB03 6088 & $967.8 \mathrm{c}$ & $625.6 \mathrm{~b}$ & $287.3 \mathrm{c}$ & $87.0 \mathrm{c}$ \\
\hline RB86 7515 & $973.0 \mathrm{~b}$ & $651.6 \mathrm{a}$ & $286.5 \mathrm{c}$ & $61.8 \mathrm{c}$ \\
\hline RB96 6928 & $946.2 \mathrm{f}$ & $584.5 \mathrm{c}$ & $312.1 \mathrm{c}$ & $103.3 \mathrm{~b}$ \\
\hline RB85 5113 & $955.9 \mathrm{e}$ & $560.7 \mathrm{~d}$ & $315.6 \mathrm{c}$ & $123.7 \mathrm{a}$ \\
\hline RB92 579 & $958.2 \mathrm{~d}$ & $623.8 \mathrm{~b}$ & $301.3 \mathrm{c}$ & $74.9 \mathrm{c}$ \\
\hline RB03 6085 & $953.4 \mathrm{e}$ & $567.2 \mathrm{~d}$ & $352.5 \mathrm{~b}$ & $80.3 \mathrm{c}$ \\
\hline RB85 5035 & $952.7 \mathrm{e}$ & $557.3 \mathrm{~d}$ & $353.8 \mathrm{~b}$ & $88.9 \mathrm{~b}$ \\
\hline RB85 5453 & $955.9 \mathrm{e}$ & $597.0 \mathrm{c}$ & $294.1 \mathrm{c}$ & $108.8 \mathrm{a}$ \\
\hline RB03 6059 & $955.6 \mathrm{e}$ & $608.6 \mathrm{c}$ & $283.5 \mathrm{c}$ & $107.9 \mathrm{a}$ \\
\hline RB03 6091 & $958.5 \mathrm{~d}$ & $673.2 \mathrm{a}$ & $262.5 \mathrm{c}$ & $64.2 \mathrm{c}$ \\
\hline RB016916 & $959.4 \mathrm{~d}$ & $626.1 \mathrm{~b}$ & $279.3 \mathrm{c}$ & $94.7 \mathrm{~b}$ \\
\hline RB94 6903 & $963.0 \mathrm{c}$ & $588.7 \mathrm{c}$ & $293.3 \mathrm{c}$ & $117.9 \mathrm{a}$ \\
\hline RB85 5546 & $960.2 \mathrm{~d}$ & $561.2 \mathrm{~d}$ & $345.0 \mathrm{~b}$ & $93.6 \mathrm{~b}$ \\
\hline RB01 6913 & $972.5 \mathrm{~b}$ & $617.7 \mathrm{~b}$ & $288.9 \mathrm{c}$ & $93.3 \mathrm{~b}$ \\
\hline RB85 5036 & $975.2 \mathrm{~b}$ & $623.5 \mathrm{~b}$ & $313.5 \mathrm{c}$ & $62.9 \mathrm{c}$ \\
\hline RB03 6152 & $966.8 \mathrm{c}$ & $626.6 \mathrm{~b}$ & $310.3 \mathrm{c}$ & $63.1 \mathrm{c}$ \\
\hline RB83 5054 & $961.8 \mathrm{~d}$ & $613.1 \mathrm{c}$ & $296.5 \mathrm{c}$ & $90.3 \mathrm{~b}$ \\
\hline RB85 5156 & $969.7 \mathrm{c}$ & $596.7 \mathrm{c}$ & $333.9 \mathrm{~b}$ & $70.4 \mathrm{c}$ \\
\hline RB85 5536 & $952.3 \mathrm{e}$ & $573.3 \mathrm{~d}$ & $361.0 \mathrm{~b}$ & $65.6 \mathrm{c}$ \\
\hline RB92 8064 & $965.6 \mathrm{c}$ & $643.7 \mathrm{a}$ & $283.1 \mathrm{c}$ & $73.1 \mathrm{c}$ \\
\hline RB72 454 & $969.5 \mathrm{c}$ & $518.2 \mathrm{e}$ & $369.1 \mathrm{~b}$ & $112.7 \mathrm{a}$ \\
\hline SEM & 1.5 & 10.0 & 13.1 & 8.7 \\
\hline
\end{tabular}

Means followed by different letters in the column differ statistically by the Scott Knott Test at 5\% probability; TC: total carbohydrates; Fraction A: soluble sugars with rapid ruminal degradation; B1: rapidly degradable carbohydrates (starch and pectin); B2: potentially degradable carbohydrates with slow degradation rate; $\mathrm{C}$ : indigestible carbohydrates; SEM: Standard error of mean. 
Table 5. In vitro digestibilities of dry matter (IVDMD), organic matter (IVOMD) and neutral detergent fiber (IVNDFD) of sugarcane cultivars $\left(\mathrm{g} \mathrm{kg}^{-1} \mathrm{DM}\right)$

\begin{tabular}{c|c|c|c}
\hline Cultivar & IVDMD & IVOMD & IVNDFD \\
\hline RB92 5345 & $727.0 \mathrm{c}$ & $764.2 \mathrm{c}$ & $374.7 \mathrm{~b}$ \\
\hline RB865230 & $755.0 \mathrm{~b}$ & $794.3 \mathrm{~b}$ & $289.7 \mathrm{c}$ \\
\hline RB956911 & $682.9 \mathrm{~d}$ & $721.1 \mathrm{~d}$ & $423.7 \mathrm{~b}$ \\
\hline RB835486 & $714.8 \mathrm{c}$ & $751.8 \mathrm{c}$ & $502.6 \mathrm{a}$ \\
\hline RB835089 & $750.7 \mathrm{~b}$ & $784.3 \mathrm{~b}$ & $473.0 \mathrm{a}$ \\
\hline RB845210 & $734.6 \mathrm{c}$ & $779.2 \mathrm{~b}$ & $452.3 \mathrm{a}$ \\
\hline RB98 6419 & $755.1 \mathrm{~b}$ & $791.4 \mathrm{~b}$ & $450.7 \mathrm{a}$ \\
\hline RB036066 & $694.8 \mathrm{c}$ & $740.2 \mathrm{~d}$ & $458.0 \mathrm{a}$ \\
\hline RB036088 & $770.7 \mathrm{~b}$ & $811.8 \mathrm{~b}$ & $440.2 \mathrm{a}$ \\
\hline RB867515 & $809.6 \mathrm{a}$ & $852.0 \mathrm{a}$ & $451.2 \mathrm{a}$ \\
\hline RB96 6928 & $756.1 \mathrm{~b}$ & $799.8 \mathrm{~b}$ & $437.8 \mathrm{a}$ \\
\hline RB855113 & $716.2 \mathrm{c}$ & $754.3 \mathrm{c}$ & $400.1 \mathrm{~b}$ \\
\hline RB92579 & $802.9 \mathrm{a}$ & $852.2 \mathrm{a}$ & $479.5 \mathrm{a}$ \\
\hline RB036085 & $753.3 \mathrm{~b}$ & $798.6 \mathrm{~b}$ & $439.2 \mathrm{a}$ \\
\hline RB855035 & $757.3 \mathrm{~b}$ & $797.6 \mathrm{~b}$ & $482.3 \mathrm{a}$ \\
\hline RB855453 & $713.8 \mathrm{c}$ & $735.9 \mathrm{~d}$ & $417.0 \mathrm{~b}$ \\
\hline RB036059 & $711.7 \mathrm{c}$ & $741.3 \mathrm{~d}$ & $400.6 \mathrm{~b}$ \\
\hline RB036091 & $787.5 \mathrm{a}$ & $822.9 \mathrm{a}$ & $485.9 \mathrm{a}$ \\
\hline RB016916 & $732.9 \mathrm{c}$ & $769.4 \mathrm{c}$ & $413.5 \mathrm{~b}$ \\
\hline RB946903 & $702.8 \mathrm{c}$ & $740.2 \mathrm{~d}$ & $388.5 \mathrm{~b}$ \\
\hline RB85 5546 & $700.2 \mathrm{c}$ & $731.2 \mathrm{~d}$ & $445.6 \mathrm{a}$ \\
\hline RB016913 & $740.7 \mathrm{~b}$ & $774.6 \mathrm{c}$ & $475.7 \mathrm{a}$ \\
\hline RB855036 & $742.1 \mathrm{~b}$ & $768.7 \mathrm{c}$ & $468.3 \mathrm{a}$ \\
\hline RB036152 & $758.1 \mathrm{~b}$ & $793.5 \mathrm{~b}$ & $518.3 \mathrm{a}$ \\
\hline RB835054 & $704.8 \mathrm{c}$ & $752.7 \mathrm{c}$ & $336.0 \mathrm{c}$ \\
\hline RB85 5156 & $705.9 \mathrm{c}$ & $748.7 \mathrm{c}$ & $458.1 \mathrm{a}$ \\
\hline RB85 5536 & $729.9 \mathrm{c}$ & $768.2 \mathrm{c}$ & $472.0 \mathrm{a}$ \\
\hline RB92 8064 & $724.6 \mathrm{c}$ & $763.4 \mathrm{c}$ & $394.4 \mathrm{~b}$ \\
\hline RB72 454 & $648.9 \mathrm{~d}$ & $689.6 \mathrm{e}$ & $463.4 \mathrm{a}$ \\
\hline SEM & 12.0 & 12.3 & 21.18 \\
\hline
\end{tabular}

Means followed by different letters in the column differ statistically by the Scott Knott Test at $5 \%$ probability; SEM: Standard error of mean.

Regarding IVNDFD, 19 cultivars showed higher values, but similar to each other, with an average of $466.0 \mathrm{~g} \mathrm{~kg}^{-1} \mathrm{DM}$. Intermediate values were obtained for cultivars RB92 5345; RB95 6911; RB85 5113; RB01 6916; RB94 6903; RB85 5453; RB03 6059 and RB92 8064 , which presented an average of $407.1 \mathrm{~g} \mathrm{~kg}^{-1} \mathrm{DM}(\mathrm{P}<0.05)$. The lowest IVNDFD values occurred in cultivars RB86 5230 and RB83 5054, which presented an average of $312.9 \mathrm{~g} \mathrm{~kg}^{-1}$ DM. The low IVNDFD of the cultivar RB86 5230 occurred due to the high concentration of indigestible carbohydrates ( $\mathrm{C}$ fraction), while in the RB83 5054 it may have occurred due to the lower proportion of potentially degradable carbohydrates (B2 fraction).

Carvalho et al. (2010) evaluated the composition and digestibility of sugarcane and suggested that from the point of view of ruminant nutrition, fiber digestibility would be a more limiting factor for animal performance than DM digestibility, since the stalk presents a greater value of IVDMD and lesser IVNDFD. The lower digestibility of the fiber is related to its complexation with lignin, which reduces the use by the animal. However, in the present study, 
the IVNDFD of most cultivars was higher than those obtained by Oliveira et al. (2007) that evaluated the cultivars RB83 5453 and IAC86 2480 and obtained mean values of 348.0 and $393.1 \mathrm{~g} \mathrm{~kg}^{-1} \mathrm{DM}$, respectively.

\section{Conclusion}

Cultivars RB03 6091, RB92 579 and RB 867515 stood out for presenting lesser indigestible carbohydrate content, greater concentration of rapidly degradable carbohydrates and greater in vitro digestibility of dry matter and organic matter demonstrating potential for use in ruminant feeding.

\section{References}

Andrade, J. B. et al. (2004). Composição química de genótipos de cana-de-açúcar em duas idades, para fins de nutrição animal. Bragantia, 63, 341-349. https://doi.org/10.1590/S0006-87052004000300004

AOAC - Association of Official Analytical Chemists. (1990). Official methods of analysis of Association of Official Analytical Chemists, (15th ed.) Arlington, 1298 p.

Bezerra, J. D. C. et al. (2017). Biometric and chemical characteristics of sugarcane varieties for use as forage in limiting soil water conditions. Revista Brasileira de Zootecnia, 46, 384-392. https://doi.org/10.1590/s1806-92902017000500003

Bonomo, P. et al. (2009). Potencial forrageiro de variedades de cana-de-açúcar para alimentação de ruminantes. Acta Scientiarum. Animal Sciences, 31, 53-59. https://doi.org/10.4025/actascianimsci.v31i1.498

Carvalho, M. V. et al. (2010). Composição bromatológica e digestibilidade de cana-de-açúcar colhida em duas épocas do ano. Brazilian Journal of Veterinary Research and Animal Science, 47, 298-306. https://doi.org/10.11606/issn.1678-4456.bjvras.2010.26829

Caviglione, J. H. et al. (2000). Cartas climáticas do Paraná. Londrina: IAPAR.

Costa, M. K. L. et al. (2017). Nutritional value of sugarcane varieties in relation to nitrogen fertilization for the pre-Amazon Region of Brazil. Semina: Ciências Agrárias, 38, 2091-2106. http://dx.doi.org/10.5433/1679-0359.2017v38n4p2091

Cruz, P. G. et al. (2010). Fractionation and kinetics of in vitro ruminal fermentation of the carbohydrates of five sugarcane varieties. Ciência Animal Brasileira, 11, 784-793. http://dx.doi.org/10.5216/cab.v11i4.4804

Daniel, J. L. P. et al. (2016). Fibre digestibility and its relationships with chemical and morphological traits in thirty-two sugarcane varieties. Grass and Forage Science, 72, 545-555. https://doi.org/10.1111/gfs.12254

Ezequiel, J. M. B. et al. (2005). Processamento da Cana-de-Açúcar: Efeitos sobre a Digestibilidade, o Consumo e a Taxa de Passagem. Revista Brasileira de Zootecnia, 34, 1704-1710. https://doi.org/10.1590/S1516-35982005000500032 
Fernandes, A. M. et al. (2003). Composição químico-bromatológica de variedades de cana de-açúcar (Saccharum spp. L.) com diferentes ciclos de produção (precoce e intermediário) em três idades de colheita. Revista Brasileira de Zootecnia, 32, 977-985. https://doi.org/10.1590/S1516-35982003000400025.

Freitas, A. W. P. et al. (2006). Avaliação da divergência nutricional de genótipos de cana-de-açúcar (Saccharum spp.). Revista Brasileira de Zootecnia, 35, 229-236. https://doi.org/10.1590/S1516-35982006000100029

Goering, H. K., \& Van Soest P. J. (1975). Forage fiber analyses (apparatus, regents, procedures, and some applications). Agriculture Handbook, n. 379. United States Department of Agriculture, $20 \mathrm{p}$.

Holden, L. A. (1999). Comparison of methods of in vitro dry matter digestibility for ten feeds. Journal of Dairy Science, 82, 1791-1794. https://doi.org/10.3168/jds.S0022-0302(99)75409-3

Klein, V. (2010). Características agronômicas, químicas e bromatológicas de variedades de cana-de-açúcar para uso forrageiro. Dissertation (M.Sc.). Universidade Federal de Goiás, Jataí, Brazil.

Magalhães J. A. et al. (2018). Produção e composição química de variedades de cana-de-açúcar com fins forrageiros sob irrigação e adubação. Pubvet, 12, 1-10. https://doi.org/10.31533/pubvet.v12n12a230.1-10

Mello, S. Q. S. et al. (2006). Parâmetros do valor nutritivo de nove variedades de cana-de-açúcar cultivadas sob irrigação. Ciência Animal Brasileira, 7, 373-380.

Miranda, A. S. et al. (2015). Production and chemical composition of three sugarcane cultivars grown under Af climate conditions. Revista Brasileira de Zootecnia, 44, 384-389. https://doi.org/10.1590/S1806-92902015001100002

Muraro, G. B. et al. (2009). Efeito da idade de corte sobre a composição bromatológica e as características da silagem de cana-de-açúcar plantada em dois espaçamentos e três idades de corte. Revista Brasileira de Zootecnia, 38, 1525-1531. https://doi.org/10.1590/S1516-35982009000800017

Oliveira, M. D. O. et al (2008). Efeito da hidrólise com cal virgem sobre a composição bromatológica da cana-de-açúcar. Veterinária Notícias, 4, 19-27.

Oliveira, M. D. S. et al. (2007). Digestibilidade da cana-de-açúcar hidrolisada, in natura e ensilada para bovinos. Ciência Animal Brasileira, 8, 41-50.

Oliveira, M. D. S. et al. (2012). Bromatological characteristics and in vitro digestibility of four sugarcane varieties subjected or not to the application of quicklime. Acta Scientiarum. Animal Science, 34, 355-361. https://doi.org/10.4025/actascianimsci.v34i4.13775

Santos, H. G. et al. (2013). Sistema brasileiro de classificação de solos. (3 ed.) Brasília: Embrapa. 353p.

Schmidt, P. et al. (2007). Aditivos químicos e biológicos na ensilagem de cana-de-açúcar. 1. 


\section{Macrothink}

Journal of Agricultural Studies

ISSN 2166-0379

2020, Vol. 8, No. 2

Composição química das silagens, ingestão, digestibilidade e comportamento ingestivo. $\begin{array}{lllll}\text { Revista Brasileira } \quad \text { Zootecnia, } & 36, & 1666-1675 .\end{array}$ https://doi.org/10.1590/S1516-35982007000700027.

Segato, S. V., Mattiuz, C. F. M. \& Mozambani, A. E. (2006). Aspectos Fenológicos da Cana-De-Açúcar. In: Segato, S.V., Pinto, A.S. \& Nóbrega J. C. M. (Eds) Atualização em produção de cana-de-açúcar. (pp. 19-36), 1st. ed. Livroceres, Piracicaba.

Silva, E. J. A. et al. (2008). Efeitos do teor de carboidratos solúveis sobre as características da silagem de cana-de-açúcar. Revista Brasileira de Zootecnia, 37, 1375-1382. https://doi.org/10.1590/S1516-35982008000800006

Siqueira, G. R. et al. (2012). Uso da cana-de-açúcar na alimentação de ruminantes. Revista Brasileira de Saúde e Produção Animal, 13, 991-1008. https://doi.org/10.1590/S1519-99402012000400011

Sniffen, C. J. et al. (1992). A net carbohydrate and protein system for evaluating cattle diets: II. Carbohydrates and protein availability. Journal of Animal Science, 70, 3562-3577. https://doi.org/10.2527/1992.70113562x

Sunahara, S. M. M. et al. (2018). Fractionation of carbohydrates and proteins in Tifton 85 bermudagrass hay at different cutting levels and storage time. Bioscience Journal, 34, 1663-1673. https://doi.org/10.14393/BJ-v34n6a2018-39810

Tiago, L. R. L. S., \& Vieira, J. M. (2002). Cana de açúcar: uma alternativa de alimento para a seca. Comunicado técnico 73. Embrapa.

Tilley, J. M. A., \& Terry, R. A. (1963). A two-stage technique for the in vitro digestion of forage crops. Journal of the British Grassland Society, 18, 104-111. https://doi.org/10.1111/j.1365-2494.1963.tb00335.x

Van Soest, P. J. (1994). Nutritional ecology of the ruminant. (2nd.ed.) London: Comstock Publishing Associates - Cornell University Press, 476p.

Van Soest, P. J., Robertson, J. B., \& Lewis, B. A. (1991). Methods for dietary fiber, neutral detergent fiber, and nonstarch polysaccharides in relation to animal nutrition. Journal of $\begin{array}{lll}\text { Dairy } & \text { Science, } & \text { 34, 3583-3597. }\end{array}$ https://doi.org/https://doi.org/10.3168/jds.S0022-0302(91)78551-2

\section{Copyright Disclaimer}

Copyright for this article is retained by the author(s), with first publication rights granted to the journal.

This is an open-access article distributed under the terms and conditions of the Creative Commons Attribution license (http://creativecommons.org/licenses/by/4.0/). 